\title{
Anthropogenic carbon dynamics in the changing ocean
}

\author{
J. F. Tjiputra ${ }^{1,2}$, K. Assmann ${ }^{2, *}$, and C. Heinze ${ }^{1,2}$ \\ ${ }^{1}$ Geophysical Institute, University of Bergen, Allégaten 70, Bergen, 5007, Norway \\ ${ }^{2}$ Bjerknes Centre for Climate Research, Allégaten 55, Bergen, 5007, Norway \\ *now at: British Antarctic Survey, High Cross, Madingley Road, Cambridge, CB3 0ET, UK
}

Received: 23 February 2010 - Published in Ocean Sci. Discuss.: 3 March 2010

Revised: 10 June 2010 - Accepted: 11 June 2010 - Published: 1 July 2010

\begin{abstract}
The long-term response of $\mathrm{CO}_{2}$ fluxes to climate change at the ocean surface and within the ocean interior is investigated using a coupled climate-carbon cycle model. This study also presents the first attempt to quantify the evolution of lateral transport of anthropogenic carbon under future climate change. Additionally, its impact on regional carbon storage and uptake is also evaluated. For the 1850 2099 period, our climate change simulation predicts oceanic uptake of anthropogenic carbon of about $538 \pm 23 \mathrm{Pg}$ C. Another simulation indicates that changes in physical climate and its associated biogeochemical feedbacks result in a release of natural carbon of about $22 \pm 30 \mathrm{PgC}$. The natural carbon outgassing is attributed to the reduction in solubility and change in wind pattern in the Southern Hemisphere. After the anthropogenic carbon passes through the air-sea interface, it is predominantly transported along the large scale overturning circulation below the surface layer. The spatial variations in the transport patterns in turn influence the evolution of future regional carbon uptake. In the North Atlantic, a slow down in the Atlantic Meridional Overturning Circulation weakens the penetration strength of anthropogenic carbon into the deeper ocean, which leads to a reduced uptake rate in this region. In contrast, more than half of the anthropogenic carbon taken up in the high latitude Southern Ocean region (south of $58^{\circ} \mathrm{S}$ ) is efficiently and continuously exported northward, predominantly into intermediate waters. This transport mechanism allows continuous increase in future carbon uptake in the high latitude Southern Ocean, where the annual uptake strength could reach $39.3 \pm 0.9 \mathrm{~g} \mathrm{C} \mathrm{m}^{-2} \mathrm{yr}^{-1}$, more than twice the global mean of $16.0 \pm 0.3 \mathrm{~g} \mathrm{C} \mathrm{m}^{-2} \mathrm{yr}^{-1}$ by the end of the 21 st century. Our study further underlines the key role of the Southern Ocean in controlling long-term future carbon uptake.
\end{abstract}

Correspondence to: J. F. Tjiputra (jerry.tjiputra@bjerknes.uib.no)

\section{Introduction}

The World Ocean is a major sink for the anthropogenic carbon emitted since 1750 (Sabine et al., 2004; Le Quéré et al., 2009). Air-sea carbon fluxes depend on physical, chemical, and biological processes. They change with increasing atmospheric $\mathrm{CO}_{2}$ concentrations in a complex adjustment process. Climate change resulting from higher atmospheric $\mathrm{CO}_{2}$ concentration induces different feedback mechanisms that could further complicate the prediction of future strength and distribution of oceanic carbon sinks.

A historically important climate-carbon cycle feedback is the variability of the ocean circulation associated with past climate change. This feedback has been shown to play a major role in controlling the distribution of deep ocean carbon storage, and therefore the regional air-sea $\mathrm{CO}_{2}$ fluxes (Wallace, 2001; Olsen et al., 2006; Takahashi et al., 2006; Toggweiler et al., 2006; Watson and Naveira-Garabato, 2006; Smith et al., 2008; Thomas et al., 2008; Cao et al., 2009). Understanding how current and future climate variability affects the time-evolving ocean circulation and the associated distribution of deep ocean carbon is important to understand future net air-sea $\mathrm{CO}_{2}$ fluxes.

In previous years, several studies have estimated the lateral transport of carbon in different ocean regions (Sarmiento et al., 1992; Stoll et al., 1996; Holfort et al., 1998; Álvarez et al., 2003; Macdonald et al., 2003; Mikaloff Fletcher et al., 2006; Gruber et al., 2009; Ito et al., 2010). These studies in general were limited by the consideration of fixed present-day internal oceanic carbon transport rates. They thus neglected the potential change of carbon transport rates in response to anthropogenic climate change. Currently, an Earth system model is the only tool that can simulate the complex interactions and long-term feedback effects between the global climate and carbon cycle. In this study, we apply such a model to quantitatively estimate the long-term response of oceanic carbon fluxes, transports, and storage. In addition,

Published by Copernicus Publications on behalf of the European Geosciences Union. 
Table 1. List of all performed experiments for the 1850-2099 period. PRE represents preindustrial (i.e., $284.7 \mathrm{ppm}$ ) whereas HA2 represents historical and IPCC-A2 emission scenario-based atmospheric $\mathrm{CO}_{2}$ concentration.

\begin{tabular}{lcc}
\hline Experiment & Climate & $\mathrm{CO}_{2}$ \\
\hline EXP1 & PRE & PRE \\
EXP2 & HA2 & HA2 \\
EXP3 & HA2 & PRE \\
\hline
\end{tabular}

the implication of regional transport and storage variability on the future regional air-sea $\mathrm{CO}_{2}$ fluxes and inventories will be determined.

\section{Experimental design}

Here, we use the Bergen Earth system model (BCM-C) (Tjiputra et al., 2010), which is based on the extension of Bergen Climate Model (Furevik et al., 2003; Otterå et al., 2009). The atmosphere component is the spectral atmospheric general circulation model ARPEGE from MeteoFrance (Déqué et al., 1994). The physical ocean component is based on the Miami Isopycnic Coordinate Ocean Model (MICOM) and is documented in Bleck and Smith (1990) and Bleck et al. (1992). Updates to our model code are described in Bentsen et al. (2004) and Assmann et al. (2010). For the carbon cycle interactions, the Lund-PotsdamJena model (LPJ) represents the terrestrial biosphere (Sitch et al., 2003) and the marine carbon cycle is represented by the Hamburg Ocean Carbon Cycle model (HAMOCC5.1) (Maier-Reimer et al., 2005). Note that the LPJ model does not include a land-use change parameterization. The marine biogeochemical model HAMOCC5.1 was adapted for use in the isopycnic physical ocean model MICOM (Assmann et al., 2010). The horizontal resolution of the model is approximately $2.8^{\circ} \times 2.8^{\circ}$. A more detailed description of the model components is available in Tjiputra et al. (2010).

The BCM-C is applied in three multi-century simulations for the period of 1850-2099 (see Table 1): (1) "EXP1", where all physical and atmospheric $\mathrm{CO}_{2}$ forcings are held at preindustrial level (PRE, i.e., a constant value of $284.7 \mathrm{ppmv}$ value is used for both the carbon fluxes and radiative forcing computations), (2) "EXP2", with interactive climate and carbon cycle evolution based on a prescribed historical and the SRES-A2 $\mathrm{CO}_{2}$ emissions scenario (Marland et al., 2005; Houghton and Hackler, 2002), and finally (3) "EXP3", where we prescribe the atmospheric $\mathrm{CO}_{2}$ concentration from EXP2 for the radiative forcing computation, but a preindustrial $\mathrm{CO}_{2}$ concentration is used for the terrestrial and oceanic carbon fluxes computation.

Here, EXP1 represents the control climate simulation with atmospheric $\mathrm{CO}_{2}$ concentration reference from the year
1850. Therefore, EXP1 simulates only the natural carbon variability between different reservoirs under preindustrial climate conditions. EXP2 represents the fully coupled simulation, which includes all feedbacks including biological, physical, and chemical feedbacks with increasing atmospheric $\mathrm{CO}_{2}$ concentration. Both the natural and anthropogenic carbon variabilities are simulated together in EXP2. Similar to EXP1, EXP3 only represents the variability of natural carbon fluxes for both the terrestrial and ocean, but under the climate change condition. The three experiments are thus designed such that the quantitative carbon difference between EXP3 and EXP1 represents the approximate change in natural carbon $\left(\mathrm{C}_{\text {nat }}\right)$ resulting from climate change, whereas the difference between EXP2 and EXP3 represents the response of anthropogenic carbon $\left(\mathrm{C}_{\mathrm{ant}}\right)$ under the projected future climate change.

For the analysis, we compute the regional and temporal variations of $\mathrm{C}_{\text {nat }}$ and $\mathrm{C}_{\text {ant }}$ uptake at the air-sea interface. In addition, the lateral transports of $\mathrm{C}_{\mathrm{ant}}$ within different ocean basins are quantified. For each latitude, the meridional carbon transport is computed by summing up the net northward dissolved inorganic carbon (DIC) transport over all vertical layers:

$\Psi_{\mathrm{CO} 2}(j, t)=\int_{x} \int_{z} C \cdot V d z d x$.

where $j$ represents latitudes, $t$ represents time, and $x, z$ represent the zonal and vertical distribution of model grid points. Here, $C$ and $V$ are the prognostic DIC concentration and the net northward volume transport leaving the grid cell, respectively. Thus, the meridional anthropogenic carbon transport, $\mathrm{C}_{\text {ant }}$ at a specific latitude and time, is simply the difference of computed $\Psi_{\mathrm{CO} 2}$ between EXP2 and EXP3. Note that the model simulates a reasonable range of present-day maximum Atlantic Meridional Overturning Circulation (AMOC) strength of 19-22 Sv, consistent with a multi-GCMs study (Schmittner et al., 2005).

\section{Model validation}

The model captures the general characteristics of observed climate variability. It also simulates realistically the large scale structure of the global ocean stream function (Furevik et al., 2003). The simulated climate change and carbon fluxes are well within range of other earth system models (Friedlingstein et al., 2006; Tjiputra et al., 2010). In the simulation of the 1990 s, the annual mean anthropogenic carbon uptake across the air-sea interface is $2.35 \pm 0.1 \mathrm{Pg} \mathrm{C} \mathrm{yr}^{-1}$, well within the range of independent estimates from an inversion study of $2.2 \pm 0.25 \mathrm{Pg} \mathrm{Cyr}^{-1}$ (Mikaloff Fletcher et al., 2006) as well as recently published $p \mathrm{CO}_{2}$ climatology-based estimates of $2.0 \pm 1.0 \mathrm{Pg} \mathrm{Cyr}^{-1}$ (Takahashi et al., 2009). Here, the model error estimates represent the standard deviation of the residuals between the model simulated annual 
variability and the respective model five-year running mean curve. The model also reproduces well the observed estimates of the large-scale distribution of air-sea carbon fluxes. Regions of mean outgassing comprise the familiar upwelling regions such as the tropical regions, with strongest outflux in the eastern Equatorial Pacific. Uptake regions are simulated in the temperate regions between $30^{\circ}$ and $60^{\circ}$ latitudes of both hemispheres. For the Antarctic polar region (south of $58^{\circ} \mathrm{S}$ ), BCM-C simulates a contemporary net carbon sink of $0.25 \pm 0.01{\mathrm{PgC} \mathrm{yr}^{-1}}^{-1}$ For the same region, an observationbased study suggest a net carbon source of $0.04 \mathrm{Pg} \mathrm{C} \mathrm{yr}^{-1}$ (Takahashi et al., 2009), whereas inversion studies suggests a similar sink of $\sim 0.2 \pm 0.1 \mathrm{Pg} \mathrm{Cyr}^{-1}$ (Mikaloff Fletcher et al., 2006, 2007).

The accumulated global anthropogenic carbon uptake for the period from $1850-1999$ is $106.5 \pm 8.9 \mathrm{Pg} \mathrm{C}$. During this period, more than $48 \%$ of the anthropogenic carbon uptake through the air-sea interface occurs in the Southern Ocean (south of $18^{\circ} \mathrm{S}$ ). The greatest per-unit-area uptake occurs in the North Atlantic $\left(18^{\circ} \mathrm{N}-66^{\circ} \mathrm{N}\right)$ region, where it is responsible for nearly $13 \%$ of the total uptake, despite representing only $8 \%$ of the World Ocean area. As expected, the equatorial regions take up least anthropogenic carbon. These spatial variations in anthropogenic $\mathrm{CO}_{2}$ uptake across different regions are generally in good agreement with estimates from other studies (Sabine et al., 2004; Gerber et al., 2009; Vázquez-Rodríguez et al., 2009). A more complete evaluation of the model's performance and validation is also discussed in Tjiputra et al. (2010).

We acknowledge limitations within the BCM-C model. For example, due to the nature of the fully coupled earth system model, the simulated temporal variabilities in the airsea $\mathrm{CO}_{2}$ fluxes are not directly comparable with the recentlyreported variabilities in the Southern Ocean (Le Quéré et al., 2007), North Atlantic (Schuster and Watson, 2007), Tropical Pacific (Feely et al., 2006), and North Pacific (Takahashi et al., 2006; Keeling et al., 2004), although the internal variability simulated by the model is realistic in a statistical sense. The model generates well the spatial and temporal variability of climate metrics such as temperature, salinity, sea level pressure, and precipitation as compared to the observation estimates (Tjiputra et al., 2010). As a result, while the model is capable of simulating the internal climate variability such as the El Niño-Southern Oscillation or the North Atlantic Oscillation, the timing and strength may disagree with the observations.

In addition, we also note that the carbon fluxes in the high latitude Southern Ocean also depend strongly on the ability of the model to simulate the sea-ice extent, temperature, as well as changes in solubility of $\mathrm{CO}_{2}$ gas in sea water. Generally, the model slightly underestimates the sea-ice extent in the South Pacific Sector, especially during the winter period as compared with observations (shown in supplemental Fig. 1). This discrepancy is mainly due to the stronger mixing in this region as described in Tjiputra et al. (2010). As a

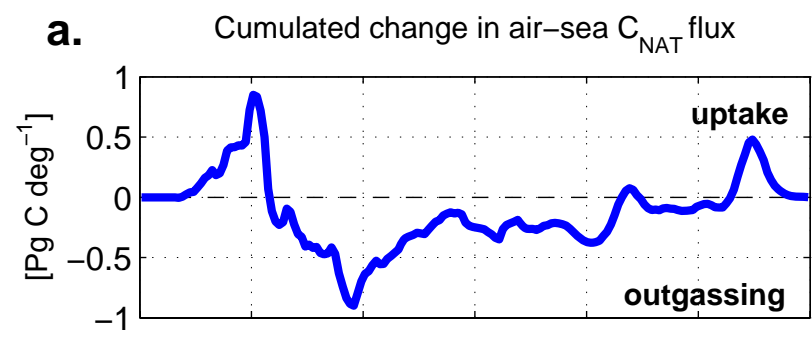

b. $\times 10^{-3}$ Change in mean surface solubility
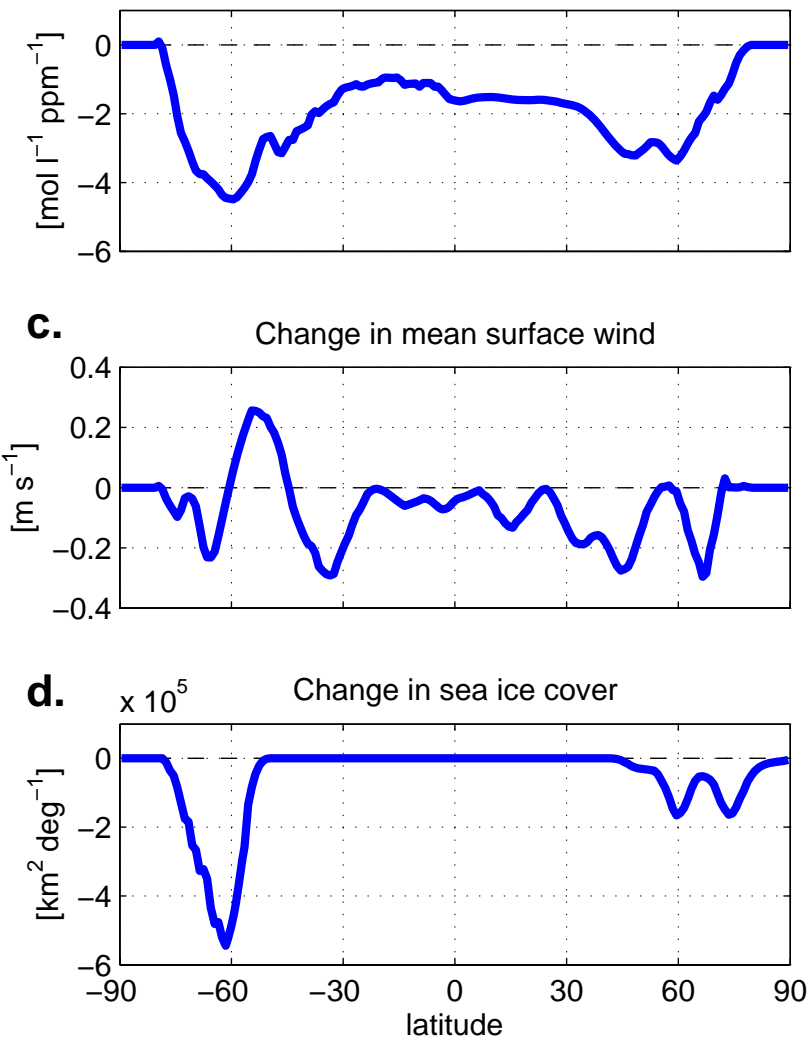

Fig. 1. Latitudinal distribution of (a) difference (EXP3-EXP1) in time-integrated air-sea $C_{\text {nat }}$ fluxes for the 1850-2099 period, difference between EXP3 and EXP1 in (b) surface solubility of $\mathrm{CO}_{2}$, (c) surface wind speed, and (d) sea ice cover computed at the end of the 21st century (2095-2099).

potential consequence, a recent multi-model study by Roy et al. (2010) shows that, in the polar Southern Ocean, the BCM$\mathrm{C}$ simulates stronger warming than the other models. For the 2010-2100 simulation period, they show that the BCM-C simulates changes in SST and $\mathrm{CO}_{2}$ solubility of $1.88^{\circ} \mathrm{C}$ and $-0.003 \mathrm{~mol} \mathrm{~kg}^{-1} \mathrm{ppm}^{-1}$ as compared to the multi-model average of $0.89 \pm 0.67^{\circ} \mathrm{C}$ and $0.0017 \pm 0.0009 \mathrm{~mol} \mathrm{~kg}^{-1} \mathrm{ppm}^{-1}$, respectively in the region south of $58^{\circ} \mathrm{S}$. 


\section{Results}

\subsection{Changes in natural carbon fluxes across the air-sea interface}

Understanding the interplay mechanisms between natural and anthropogenic carbon is essential in predicting future oceanic uptake. Several studies have indicated that the longterm balance of $\mathrm{C}_{\text {nat }}$ fluxes will be altered in the future due to climate change (Le Quéré et al., 2007; Zickfeld et al., 2007). Here, the response of $\mathrm{C}_{\text {nat }}$ fluxes across the air-sea interface to future climate perturbation is estimated by computing the difference between the results from EXP1 and EXP3. For the 1850-2099 period, the time-integrated $\mathrm{C}_{\text {nat }}$ fluxes amount to about $22 \pm 30 \mathrm{Pg} \mathrm{C}$ outgassing.

Figure 1 shows that the main $\mathrm{C}_{\text {nat }}$ outgassing regions are located in the tropical and mid-latitude regions and most of the Southern Ocean. We attribute part of the future outgassing of $\mathrm{C}_{\text {nat }}$ to SST warming, which results in reduction of gas solubility in seawater across all latitudes (see Fig. 1b).

Figure 1c also shows that our climate change simulation indicates a southward shift in the Southern Ocean westerlies wind by about five degree of latitudes (see also supplemental Fig. 2). Such feature is consistent with other studies (Fyfe and Saenko, 2006; Zickfeld et al., 2007), which also indicate a poleward shift in maximum zonal wind stress in the Southern Ocean toward the end of the 21 st century. In their study, Zickfeld et al. (2007) show that similar changes in the Southern Hemisphere winds lead to increased upwelling of DIC-rich waters and hence ventilation of $\mathrm{C}_{\text {nat }}$ south of $55^{\circ} \mathrm{S}$. In our model, the $40^{\circ} \mathrm{S}$ latitude band represents a mean influx of $\mathrm{C}_{\text {nat }}$ into the ocean. Therefore, the poleward wind shift weakens the gas transfer rate across most of this latitudinal band, which results in reduced uptake strength of $\mathrm{C}_{\text {nat }}$ (i.e., a global net outgassing).

While the study by Zickfeld et al. (2007) also resulted in net outgassing of natural carbon, it is important to note that the mechanism that is acting in their model is slightly different to the one in this study, despite a similar poleward wind shift perturbation. These discrepancies can be attributed to the spatial difference in the air-sea $\mathrm{CO}_{2}$ fluxes simulated by the two models. In addition to the zonal wind shift in our climate change simulation, a substantial retreat of sea-ice in the southern polar latitudes (shown in Fig. 1d) leads to an additional uptake of $\mathrm{C}_{\text {nat }}$ (see also Tjiputra et al., 2010).

\subsection{Anthropogenic carbon uptake and storage}

The accumulated air-sea uptake of $\mathrm{C}_{\mathrm{ant}}$ during the 18502099 period amounts to about $538 \pm 23 \mathrm{Pg}$ C. Most of this uptake is confined to the dominant $\mathrm{C}_{\mathrm{ant}}$ uptake regions similar to the present day. These regions include the North Atlantic sub-polar gyre, northwestern Pacific, Equatorial Pacific, and most of the Southern Ocean (south of $30^{\circ} \mathrm{S}$ ), as shown in Fig. 2a. Once the anthropogenic carbon passes through the

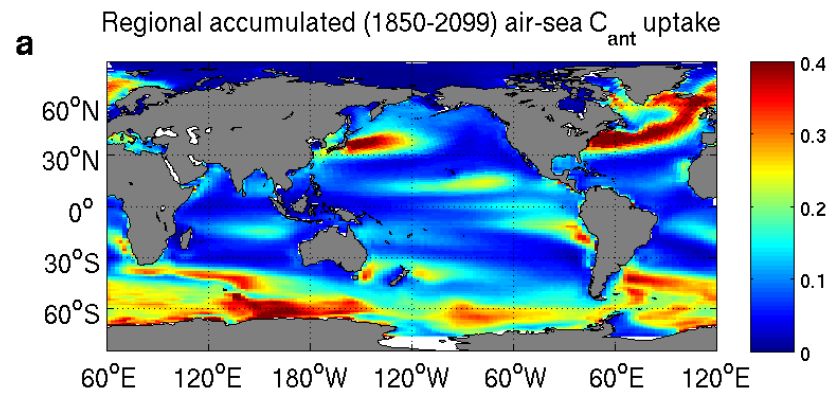

b Column inventory of $C_{\text {ant }}$ in year 2099

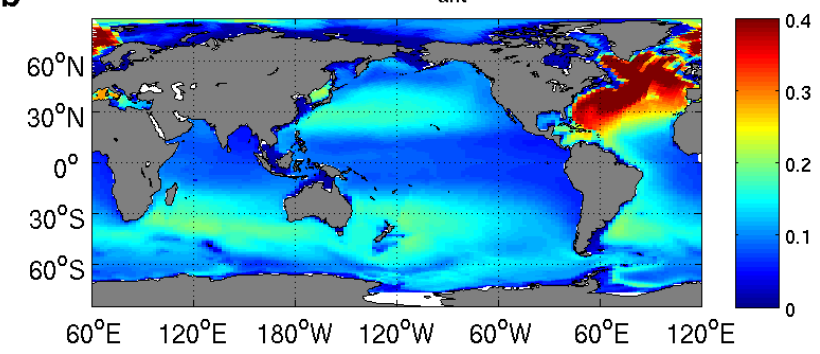

Latitudinal surface uptake and column storage of $\mathrm{C}_{\text {ant }}$

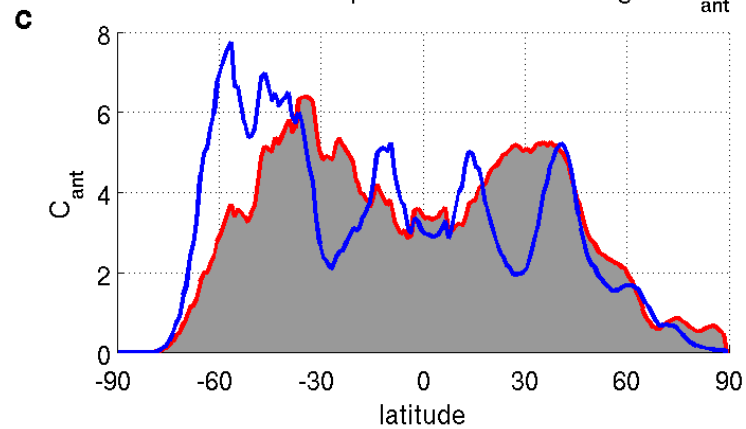

Fig. 2. Spatial distribution of (a) accumulated (1850-2099) $\mathrm{C}_{\mathrm{ant}}$ uptake across the air-sea interface $\left(\mathrm{kmol} \mathrm{C} \mathrm{m}^{-2}\right)$, (b) column inventory of $\mathrm{C}_{\text {ant }}$ at the end of experiment period $\left(\mathrm{kmol} \mathrm{C} \mathrm{m}^{-2}\right)$, and (c) latitudinal distribution of total uptake (blue-line) and storage (grey shading) of $\mathrm{C}_{\mathrm{ant}}\left(\mathrm{Pg} \mathrm{C} \mathrm{deg}^{-1}\right)$, also at the end of experiment period.

air-sea interface, it is predominantly transported along the large scale overturning circulation below the surface layer. This circulation, in turn controls the future distribution of $\mathrm{C}_{\text {ant }}$ in the deep ocean. Figure 2 illustrates that $\mathrm{C}_{\mathrm{ant}}$ is not necessarily stored in the region where it is taken up by the ocean and highlights the role of $\mathrm{C}_{\text {ant }}$ lateral transport in the ocean interior.

Figure $2 \mathrm{c}$ shows substantial uptake of $\mathrm{C}_{\text {ant }}$ between $30^{\circ} \mathrm{S}$ and $65^{\circ} \mathrm{S}$, a considerable amount of which is subsequently stored outside this region. This high-uptake-low-inventory feature in the high latitude Southern Ocean region is consistent with recent observations and modeling studies (Caldeira and Duffy, 2000; Sabine et al., 2004; Ito et al., 2010). In the Northern Hemisphere, there is a net influx of subsurface $C_{a n t}$ 
into the northern mid-latitude regions (i.e., between $10^{\circ} \mathrm{N}$ and $50^{\circ} \mathrm{N}$ ). To better understand the role of lateral transport below the surface layer, in the next subsection, we attempt to quantify the regional and temporal evolution of $\mathrm{C}_{\mathrm{ant}}$ transport.

\subsection{Anthropogenic carbon transport}

To analyse the large scale response of anthropogenic carbon lateral transport across different ocean basins, we compute the latitudinal meridional mass transport of $\mathrm{C}_{\mathrm{ant}}$ following Eq. (1). Figure 3 summarizes the simulated mean-decadal meridional migration of anthropogenic carbon across different ocean sections for the period 1850-2099 together with available present observation-based estimates as well as results from previous modeling studies.

For the early anthropocene, there is a weak and consistent meridional transport of $\mathrm{C}_{\mathrm{ant}}$, northward within both the Atlantic and Pacific, and southward in the Indian Ocean. In the Atlantic Ocean, the northward $\mathrm{C}_{\text {ant }}$ transport ranges from negligible amounts in the Northern Hemisphere to $\sim 0.02 \pm 0.004 \mathrm{PgC} \mathrm{yr}^{-1}$ in the Southern Hemisphere. The northward conveyance is due to the fact that the upper ocean waters of the Atlantic Ocean, where most of the anthropogenic $\mathrm{CO}_{2}$ resides, move predominantly northward.

Meridional transport in the Pacific Ocean occurs mostly with a similar magnitude. Near the equator, the meridional transport is very close to zero, suggesting dominant westward transport of $\mathrm{C}_{\text {ant }}$ passing the Indonesian archipelago into the Indian Ocean. Consequently, the meridional transport of $\mathrm{C}_{\text {ant }}$ in the Indian Ocean is uniformly southward with increasing magnitudes toward the south.

Figure 3 also shows that the model simulates an increasing strength of the meridional $\mathrm{C}_{\mathrm{ant}}$ transport as compared to the preindustrial period in most regions. This is expected as the ocean is continuously taking up further $\mathrm{C}_{\mathrm{ant}}$. For present day conditions (i.e., 1990s, solid black line in Fig. 3), the northward transport in the Atlantic Ocean increases significantly to nearly $0.2 \mathrm{Pg} \mathrm{C} \mathrm{yr}^{-1}$ for the region south of $15^{\circ} \mathrm{N}$, and decreases toward the Arctic. Simulated northward $\mathrm{C}_{\mathrm{ant}}$ transports for the region south of $15^{\circ} \mathrm{N}$ are in general agreement with independent estimates. Estimates from both data assimilation and inverse studies (Mikaloff Fletcher et al., 2006; Gerber et al., 2009; Gruber et al., 2009) suggest a similar pattern of northward transport of $\mathrm{C}_{\mathrm{ant}}$ in the Atlantic Ocean that is maximized in the Southern Hemisphere. An observation-based study (Holfort et al., 1998) suggests northward transport $(0.11 \pm 0.03-$ $0.26 \pm 0.03 \mathrm{Pg} \mathrm{C} \mathrm{yr}^{-1}$ ) in the region between $11^{\circ} \mathrm{S}$ and $30^{\circ} \mathrm{S}$. Previous studies have offered considerably diverging estimates of present day northward transport strength across the $24.5^{\circ} \mathrm{N}: 0.24 \pm 0.04 \mathrm{Pg} \mathrm{C} \mathrm{yr}^{-1}$ (Álvarez et al., 2003), $0.19 \pm 0.07 \mathrm{Pg} \mathrm{C} \mathrm{yr}^{-1}$ (Macdonald et al., 2003), and about $0.08 \mathrm{Pg} \mathrm{C} \mathrm{yr}^{-1}$ (Gruber et al., 2009). Our estimates are in the centre of that range, $0.15 \pm 0.04 \mathrm{PgC}^{-1}$. Disagreements
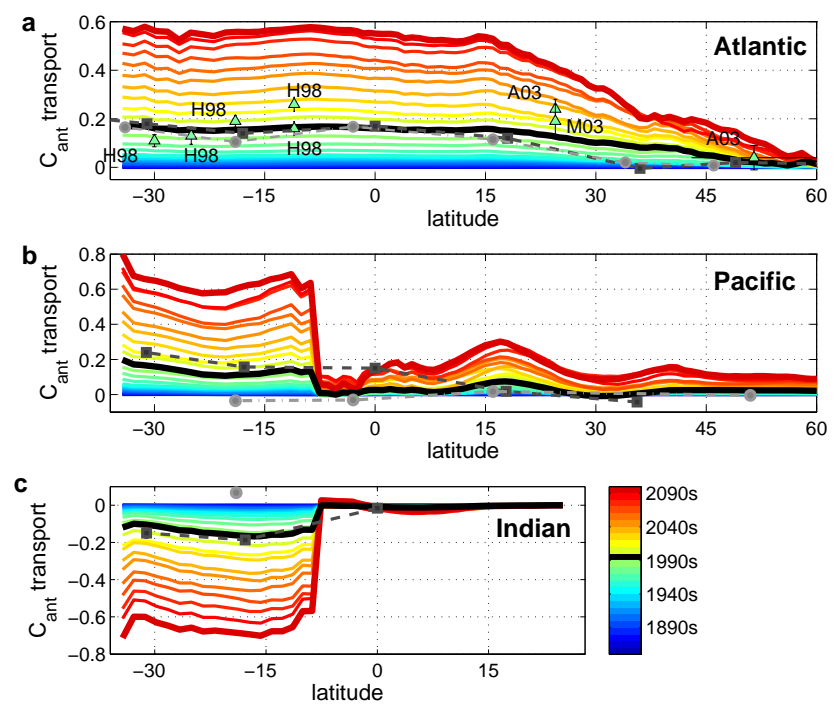

Fig. 3. Simulated meridional transport strength of $\mathrm{C}_{\mathrm{ant}}$ in the (a) Atlantic, (b) Pacific, and (c) Indian Oceans basin for the 1850-2099 period, plotted as a function of latitude. Each lines represents decadal-averaged northward fluxes. Units are in $\left(\mathrm{PgC} \mathrm{yr}^{-1}\right)$. All observational based estimates represent the present day (1990s2000s) periods. H98: Holfort et al. (1998), A03: Álvarez et al. (2003), M03: Macdonald et al. (2003), dark grey squares are from inversion study (Mikaloff Fletcher et al., 2006; Gruber et al., 2009), and light grey circles are from mean reconstruction estimates using the Ensemble Kalman Filter (Gerber et al., 2009).

can be attributed to spatial variation in the carbon uptake estimates and the large month-to-month variation in the observed meridional overturning circulation strength (Cunningham et al., 2007). In the high latitude North Atlantic, our estimates are in good agreement with other studies as shown in Fig. 3.

In the Pacific, our present day $\mathrm{C}_{\mathrm{ant}}$ transport estimate also lies between that of an inverse study and that of data-based estimates. The model simulates maximum northward transport of $0.15 \mathrm{PgC} \mathrm{yr}^{-1}$ in the South Pacific and relatively weak northward transport in the North Pacific. In the Equatorial Pacific, the model simulates almost no meridional conveyance, indicating westward transport toward the Indian Ocean.

In the Indian Ocean, our present day transport estimates agree well with the inversion study (Mikaloff Fletcher et al., 2006), with approximately $0.15 \mathrm{Pg} \mathrm{Cyr}^{-1}$ southward transport in the Southern Hemisphere and small lateral transport north of $8^{\circ} \mathrm{S}$. The former transport pattern is consistent with the zonal transport in the near-equatorial Pacific region, which carries $C_{\text {ant }}$ passing the Indonesian throughflow into the Indian Ocean. The data assimilation study by Gerber et al. (2009) assumed zero net transport across the Indonesian throughflow, which resulted in large discrepancies with our transport estimates across the South Pacific and South Indian sections. In the Indian Ocean, southward transport patterns 
are also consistent with observation based estimates (Sabine et al., 1999), which reported maximum anthropogenic $\mathrm{CO}_{2}$ concentrations south of $30^{\circ} \mathrm{S}$.

By the end of the 21st century, the latitudinal gradient in meridional anthropogenic carbon transport becomes more apparent. In the Atlantic, there is a net northward transport of anthropogenic carbon, with the greatest amplitude $\left(0.65 \mathrm{Pg} \mathrm{C} \mathrm{yr}^{-1}\right)$ in the southern portion. In the northern portion, the northward transport is weaker, which could be attributed to the horizontal and vertical return flows associated with the overturning circulation. This negative gradient in latitudinal transport of anthropogenic carbon in the Atlantic basin resulted in large amount of anthropogenic carbon $(\sim 101.4 \pm 5.7 \mathrm{PgC})$ stored between $18^{\circ} \mathrm{N}-66^{\circ} \mathrm{N}$ by the end of this century (see also Figs. 2c and 4).

The northward transport of $\mathrm{C}_{\text {ant }}$ from the Southern Ocean into the Pacific Ocean also increases significantly $\left(0.65 \mathrm{Pg} \mathrm{C} \mathrm{yr}^{-1}\right)$ toward the end of the model simulation. This northward flux is approximately offset by the southward transport from the Indian Ocean into the Southern Ocean, which resulted in relatively small net gain (i.e., in the midlatitude Southern Ocean) in carbon storage due to lateral transport to and from both the Pacific and Indian Oceans, respectively.

\section{Discussion}

In this section we discuss some implications of the $\mathrm{C}_{\mathrm{ant}}$ transport variations on the future uptake and storage of anthropogenic carbon. Figure 4 shows a large-scale overview of future time-integrated transport and inventory of anthropogenic carbon. It quantitatively illustrates the long-term accumulation of anthropogenic carbon due to the combined effects of air-sea gas exchange and lateral transport for the period of 1850-2099 in different ocean basins.

By the end of the century, in the Indian Ocean, the $\mathrm{C}_{\mathrm{ant}}$ inventory is roughly equal to the anthropogenic carbon uptake through the air-sea interface, since there are nearly equal lateral inflow (from the Indonesian throughflow) and lateral outflow (to the Southern Ocean) rates of anthropogenic carbon into and out of this region.

The model simulation shows that the Equatorial Pacific is one of the only two regions (the high latitude Southern Ocean is the other) having a net $\mathrm{C}_{\text {ant }}$ outflow. This is reflected by more $\mathrm{C}_{\mathrm{ant}}$ transported into the Indian $(-44.6 \pm 7.0 \mathrm{PgC})$ and North Pacific $(-18.0 \pm 8.1 \mathrm{PgC})$ as compared to input from Southern Ocean (37.4 $\pm 7.2 \mathrm{Pg} \mathrm{C})$. Here, the Indonesian throughflow is an important mechanism in transporting most of the $\mathrm{C}_{\text {ant }}$ taken up across the air-sea interface (in the Equatorial Pacific) to the Indian Ocean. A smaller portion of $C_{a n t}$ is transported northward to the North Pacific.

Both the North Pacific and North Atlantic Oceans exhibit similar $\mathrm{C}_{\mathrm{ant}}$ flux patterns. This is intriguing because of the fact that both the North Pacific and the North Atlantic are on the opposite ends of the global meridional overturning circulation. While most of the $\mathrm{C}_{\mathrm{ant}}$ inventory in these regions originates directly from the atmosphere, considerable amounts are imported from the southern portion of the respective ocean basins. Additionally, in the North Atlantic, the simulated climate change leads to a weakening of the Atlantic Meridional Overturning Circulation (AMOC) strength by approximately $7 \mathrm{~Sv}$. Since deep water formation associated with the AMOC is the principal mechanism for transporting $\mathrm{C}_{\mathrm{ant}}$ from surface to the deep ocean (e.g., in the North Atlantic), the weakening leads to weaker penetration of $\mathrm{C}_{\mathrm{ant}}$ into deeper layers. These mechanisms (i.e., influx of near surface $C_{a n t}$ from the south and reduced export strength) could alter the atmospheric $\mathrm{C}_{\text {ant }}$ uptake strength in the North Atlantic. For example, a recent study by Steinfeldt et al. (2009) indicates that in the subpolar North Atlantic, weakening in the formation of Labrador Sea Water has led to a decrease of the $\mathrm{C}_{\mathrm{ant}}$ inventory in this region.

In the Arctic, approximately equal amounts of the accumulated $\mathrm{C}_{\mathrm{ant}}(7.7 \pm 1.3 \mathrm{PgC}$ ) in the region come from the lateral transport and through the air-sea interface. Our transport estimates in the region are consistent with an earlier study (Lundberg and Haugan, 1996), which indicates that the total carbon flux to the Nordic Seas and Arctic Ocean is dominated by the influx through the Bering Strait.

By the end of the century, the largest time-integrated (1850-2099) $\mathrm{C}_{\mathrm{ant}}$ uptake from the atmosphere, about $185.9 \pm 12.2 \mathrm{Pg} C$, occurs in the Southern Ocean, between $18^{\circ} \mathrm{S}-58^{\circ} \mathrm{S}$. In addition, there are accumulated inflows of $44.0 \pm 7.6$ and $43.9 \pm 11.8 \mathrm{PgC}$ from the Indian and high latitude Southern Oceans, and outflows of $37.4 \pm 7.2$ and 45.5 $\pm 3.2 \mathrm{Pg} \mathrm{C}$ into the Pacific and Atlantic Oceans, respectively. These lateral fluxes combine for a net influx of only $5 \mathrm{Pg}$ of $\mathrm{C}_{\mathrm{ant}}$ over the experiment period, and make the Southern Ocean $\left(18^{\circ} \mathrm{S}-58^{\circ} \mathrm{S}\right)$ the dominant region for $\mathrm{C}_{\text {ant }}$ storage with $191.8 \pm 18.6 \mathrm{Pg} \mathrm{C}$.

Finally, the high latitude Southern Ocean region (SOC2 in Fig. 4) appears to be the only region with significant and continuous uptake and outflow of anthropogenic carbon. Figure 4 illustrates that approximately half of the $\mathrm{C}_{\text {ant }}$ absorbed in this region is subsequently transported into regions further north. This northward anthropogenic carbon transport mostly occurs along the subduction pathway of the intermediate water masses with maximum conveyance at approximately $400-500 \mathrm{~m}$ depth. A similar mechanism is hypothesized for the present day condition (Caldeira and Duffy, 2000; Gerber et al., 2009; Gruber et al., 2009; VázquezRodríguez et al., 2009; Ito et al., 2010). Our model simulation demonstrates that this $\mathrm{C}_{\mathrm{ant}}$ export pattern is robust and will continue toward the end of the 21 st century. In the model, the opening of sea ice also contributes to the increase in $\mathrm{C}_{\mathrm{ant}}$ uptake across the air-sea interface in the region. Tjiputra et al. (2010) estimated that the sea-ice retreat could increase the oceanic carbon uptake by an order of $20 \mathrm{Pg} \mathrm{C}$ for the same experiment period. 


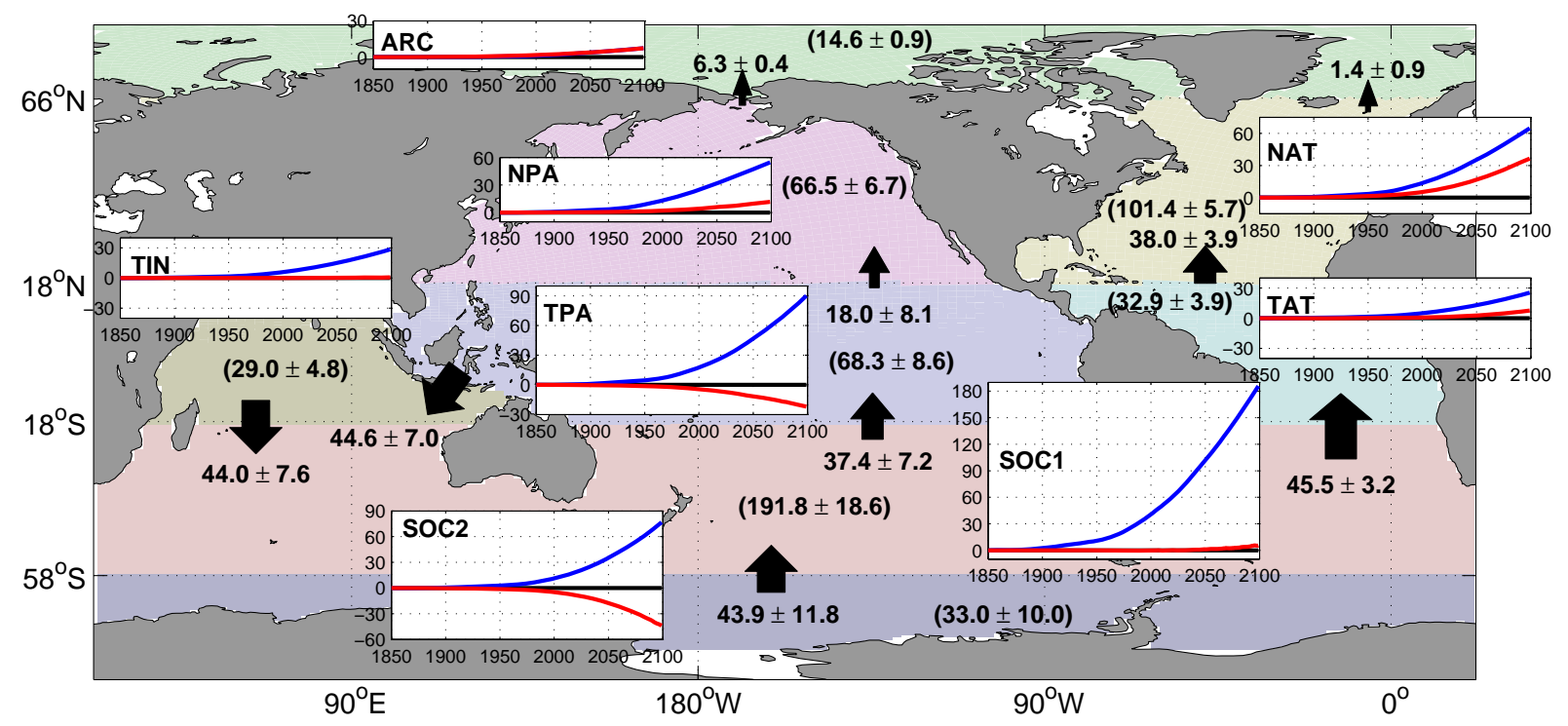

Fig. 4. Accumulated $C_{a n t}$ fluxes from the atmosphere (blue-line) as compared to lateral fluxes (red-line) into different ocean regions for the 1850-2099 period. Possitive values represent fluxes into the region and negative otherwise. Regions are defined as follow: Arctic $\left(\right.$ ARC, $>66^{\circ} \mathrm{N}$ ), North Atlantic (NAT, $18^{\circ} \mathrm{N}-66^{\circ} \mathrm{N}$ ), North Pacific (NPA, $18^{\circ} \mathrm{N}-66^{\circ} \mathrm{N}$ ), Tropical Atlantic (TAT, $\left.18^{\circ} \mathrm{S}-18^{\circ} \mathrm{N}\right)$, Tropical Pacific (TPA, $18^{\circ} \mathrm{S}-18^{\circ} \mathrm{N}$ ), Tropical Indian (TIN, $18^{\circ} \mathrm{S}-25^{\circ} \mathrm{N}$ ), mid latitude Southern Ocean (SOC1, $58^{\circ} \mathrm{S}-18^{\circ} \mathrm{S}$ ), high latitude Southern Ocean $\left(\mathrm{SOC} 2,>58^{\circ} \mathrm{S}\right)$. Arrow and number pairs represent accumulated transport fluxes of $\mathrm{C}_{\text {ant }}$ between regions for the period $1850-2099$. Numbers inside parenthesis represent the storage term of $\mathrm{C}_{\mathrm{ant}}$ in each region at the end of experiment period. All units are in (Pg C).

To link the potential role of regional lateral transport with the future $\mathrm{C}_{\text {ant }}$ uptake, we compute the evolution of regional $\mathrm{C}_{\mathrm{ant}}$ uptake for the same ocean regions discussed above, as illustrated in Fig. 5. For the present day period, the highest anthropogenic carbon uptake occurs in the North Atlantic and high latitude Southern Ocean. By the end of the century, the uptake rate in the high latitude Southern Ocean continues to increase, reaching $39.3 \pm 0.9 \mathrm{~g} \mathrm{C} \mathrm{m}^{-2}$, more than twice the global mean of $16.0 \pm 0.3 \mathrm{~g} \mathrm{C} \mathrm{m}^{-2}$. This is consistent with our previous transport analysis, which indicates efficient transport of $\mathrm{C}_{\mathrm{ant}}$ out of the high latitude Southern Ocean into deepwater areas further north. On the other hand, Fig. 5 also shows a noticeable slowing down of $\mathrm{C}_{\text {ant }}$ uptake rate in the North Atlantic and North Pacific, which can partly be attributed to the significant lateral influx of $C_{a n t}$ into the regions. We note that a near stabilization of anthropogenic carbon uptake in all ocean regions will only occur after a multi-century equilibration period (between different carbon reservoirs) following the stabilization of Cant emissions (Archer et al, 2009), which is beyond our experiment periods. In addition to the different transport mechanisms, the water masses in the high latitude regions are generally less exposed to the anthropogenic carbon as compared to the younger mid latitude water masses. Furthermore, high biological production during Spring, strong winter cooling, and mixing could lead to larger delta $p \mathrm{CO}_{2}$ values in high latitude regions (shown in supplemental Fig. 3), allowing more efficient anthropogenic carbon uptake (e.g. see also studies

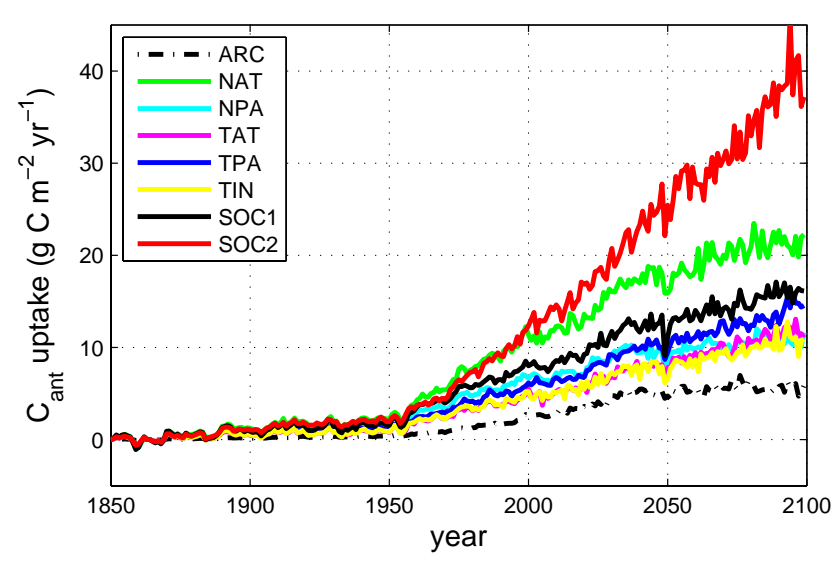

Fig. 5. Time series of area-weighted annual $C_{\text {ant }}$ uptake for different ocean regions. Region definitions are given in Fig. 4. Units are in $\left(\mathrm{g} \mathrm{C} \mathrm{m}^{-2} \mathrm{yr}^{-1}\right)$.

by Sarmiento et al., 1992, Sarmiento et al., 1998, Mignone et al., 2006, and Takahashi et al., 2009). It is also important to note that warm tropical water masses have lower Revelle factor, which implies a higher $\mathrm{CO}_{2}$ equilibrium given the same atmospheric $\mathrm{CO}_{2}$ perturbation (Sabine et al., 2004).

By the end of the century, the global ocean has taken up $538 \pm 23 \mathrm{Pg}$ of $\mathrm{C}_{\mathrm{ant}}$ in our simulation. Large portions of this amount reside in the Southern Ocean (between $18^{\circ} \mathrm{S}$ and $\left.58^{\circ} \mathrm{S}\right), 191.8 \pm 18.6 \mathrm{Pg} \mathrm{C}$, and the North Atlantic Ocean 
(between $18^{\circ} \mathrm{N}$ and $66^{\circ} \mathrm{N}$ ), 101.4 $\pm 5.7 \mathrm{Pg} \mathrm{C}$. Both regions combined account for $55 \%$ of the global inventory.

\section{Conclusions}

Recently, Earth system models have been employed to analyze the potential vulnerabilities of future ocean carbon uptake due to changes in the climate system, such as temperature and atmospheric circulation (Friedlingstein et al., 2006; Crueger et al., 2008). In this study, we applied the Bergen Earth system model to analyze the role of ocean circulation in controlling future distribution of oceanic anthropogenic $\mathrm{CO}_{2}$ concentration and its potential implication on future air-sea $\mathrm{CO}_{2}$ fluxes.

For the period of 1850-2099, outgassing of natural carbon is simulated in our model, which amounts to a total of $22 \pm 30 \mathrm{PgC}$. The accumulated uptake of anthropogenic carbon for the same period amounts to about $538 \pm 23 \mathrm{Pg} \mathrm{C}$. A similar simulation to EXP2 (not shown here) but without climate and other physical changes (see also Tjiputra et al., 2010) return an accumulated anthropogenic carbon uptake of about $560 \pm 23 \mathrm{Pg} \mathrm{C}$. Our model study thus implies that feedbacks from climate change induced circulation and other physical changes are approximately one order magnitude smaller than the ocean capacity to take up anthropogenic carbon.

Here, we determine the role of the ocean circulation in transporting the absorbed anthropogenic carbon, and the implications for regional carbon uptake in the future. Our study shows that the ability of the high latitude Southern Ocean (i.e., south of $58^{\circ} \mathrm{S}$ ) to take up anthropogenic $\mathrm{CO}_{2}$ will continue to increase in the future, in contrast to other regions which will see a reduction or slow down of anthropogenic carbon uptake. We partly attribute this acceleration of uptake (i.e., in the high latitude Southern Ocean) to the efficient subsurface northward transport of anthropogenic carbon into the intermediate waters. We also would like to stress the still considerable uncertainties about Southern Ocean carbon cycling and its variations due to climate change. Lateral transports of anthropogenic carbon in most other regions (i.e., tropical regions) prominently occur within the surface or near-surface level. Therefore, they generally do not provide efficient deepwater pathways for export of anthropogenic carbon.

In the North Atlantic, despite the high uptake rate across the air-sea interface, a substantial amount of subsurface anthropogenic carbon is transported into the region (i.e., from the tropics). This northward transport has already altered the carbon uptake rate in regions such as the Nordic Seas (Olsen et al., 2006). A continuous inflow of $\mathrm{CO}_{2}$-rich near-surface water may potentially contribute to the stabilization of carbon uptake in the North Atlantic Ocean in the future (see also Fig. 5).
All of the available observation-based estimates of anthropogenic carbon transport have been conducted in the Atlantic Ocean so far. Future observations in the Pacific and Indian Oceans would undoubtedly be useful to constrain future prediction of climate change associated carbon transport.

\section{Supplementary material related to this article is available online at: http://www.ocean-sci.net/6/605/2010/ os-6-605-2010-supplement.pdf.}

Acknowledgements. Both anonymous referees provided many useful comments, which improved the final version of the manuscript. The authors thank Are Olsen and Justin Wettstein for the constructive feedback on this manuscript. This study at the University of Bergen and Bjerknes Centre for Climate Research is supported by the EU-FP6 integrated project CarboOcean (grant no. 511176), the Research Council of Norway funded project NorClim and CarboSeason (grant no. 1805/530). The experiments in this study are also made possible through the supercomputing support from NOTUR (Norwegian Metacenter for Computational Science), biogeochemical earth system modelling project (no. nn2980k) and the respective archiving project NorStore (Norwegian Storage Infrastructure) (no. ns2980k). This is publication no. A294 from the Bjerknes Centre for Climate Research.

Edited by: A. Sterl

\section{References}

Álvarez, M., Ríos, A. F., Pérez, F. F., Bryden, H. L., and Rosón, G.: Transports and budgets of total inorganic carbon in the subpolar and temperate North Atlantic, Global Biogeochem. Cy., 17(1), 1002, doi:10.1029/2002GB001881, 2003.

Archer, D., Eby, M., Brovkin, V., Ridgwell, A., Cao, L., Mikolajewicz, U., Caldeira, K., Matsumoto, K., Munhoven, G., Montenegro, A., and Tokos, K.: Atmospheric lifetime of fossil fuel carbon dioxide, Annu. Rev. Earth Pl. Sc., 37, 117-134, 2009.

Assmann, K. M., Bentsen, M., Segschneider, J., and Heinze, C.: An isopycnic ocean carbon cycle model, Geosci. Model Dev., 3, 143-167, 2010.

Bentsen, M., Drange, H., Furevik, T., and Zhou, T.: Simulated variability of the Atlantic meridional overturning circulation, Clim. Dynam., 22, 701-720, 2004.

Bleck, R. and Smith, L. T.: A wind-driven isopycnic coordinate model of the North and Equatorial Atlantic Ocean, 1. Model development and supporting experiments, J. Geophys. Res., 95, 3273-3285, 1990.

Bleck, R., Rooth, C., Hu, D., and Smith, L. T.: Salinity-driven Thermocline Transients in a Wind- and Thermohaline-forced Isopycnic Coordinate Model of the North Atlantic, J. Phys. Oceanogr., 22, 1486-1505, 1992.

Caldeira, K. and Duffy, P. B.: The role of the Southern Ocean in the uptake and storage of anthropogenic carbon dioxide, Science, 287, 620-622, 2000. 
Cao, L., Eby, M., Ridgwell, A., Caldeira, K., Archer, D., Ishida, A., Joos, F., Matsumoto, K., Mikolajewicz, U., Mouchet, A., Orr, J. C., Plattner, G.-K., Schlitzer, R., Tokos, K., Totterdell, I., Tschumi, T., Yamanaka, Y., and Yool, A.: The role of ocean transport in the uptake of anthropogenic $\mathrm{CO}_{2}$, Biogeosciences, 6, 375-390, doi:10.5194/bg-6-375-2009, 2009.

Crueger, T., Roeckner, E., Raddatz, T., Schnur, R., and Wetzel, P.:Ocean dynamics determine the response of oceanic $\mathrm{CO}_{2}$ uptake to climate change, Clim. Dynam., 31, 151-168, doi:10.1007/s00382-007-0342-x, 2008.

Cunningham, S. A., Kanzow, T., Rayner, D., Baringer, M. O., Johns, W. E., Marotzke, J., Longworth, H. R., Grant, E. M., Hirschi, J. J.-M., Beal, L. M., Meinen, C. S., and Briden, H. L.: Temporal variability of of the Atlantic meridional overturning circulation at $26.5^{\circ} \mathrm{N}$, Science, 317(5840), 935-938, doi:10.1126/science.1141, 2007.

Déqué, M., Dreveton, C., Braun, A., and Cariolle, D.: The ARPEGE/IFS atmosphere model: A contribution to the French community climate modelling, Clim. Dynam., 10, 249-266, 1994.

Feely, R., Takahashi, T., Wanninkhof, R., McPhaden, M. J., Cosca, C. E., Sutherland, S. C., and Carr, M.-E.: Decadal variability of the air-sea $\mathrm{CO}_{2}$ fluxes in the equatorial Pacific Ocean, J. Geophys. Res., 111, C08S90, doi:10.1029/2005JC003129, 2006.

Friedlingstein, P., Cox, P., Betts, R., Bopp, L., von Bloh, W., Brovkin, V., Cadule, P., Doney, S., Eby, M., Fung, I., Gala, B., John, J., Jones, C., Joos, F., Kato, T., Kawamiya, M., Knorr, W., Lindsay, K., Matthews, H. D., Raddatz, T., Rayner, P., Reick, C., Roeckner, E., Schnitzler, K.-G., Schnur, R., Strassmann, K., Weaver, A. J., Yoshikawa, C., and Zeng, N.: Climate-carbon cycle feedback analysis: Results from the $\mathrm{C}^{4} \mathrm{MIP}$ model intercomparison, J. Climate, 19, 3337-3353, 2006.

Furevik, T., Bentsen, M., Drange, H., Kindem, I. K. T., Kvamst $\varnothing$, N. G., and Sorteberg, A.: Description and evaluation of the bergen climate model: ARPEGE coupled with MICOM, Clim. Dynam., 21, 27-51, doi:10.1007/s00382-003-0317-5, 2003.

Fyfe, J. C. and Saenko, O. A.: Simulated changes in the extratropical Southern Hemisphere winds and currents, Geophys. Res. Lett., 33, L06701, doi:10.1029/2005GL025332, 2006.

Gerber, N., Joos, F., Vázquez-Rodríguez, M., Touratier, F., and Goyet, C.: Regional air-sea fluxes of anthropogenic carbon inferred with an Ensemble Kalman Filter, Global Biogeochem. Cy., 23, GB1013, doi:10.1029/2008GB003247, 2009.

Gruber, N., Gloor, M., Mikaloff Fletcher, S. E., Doney, S. C., Dutkiewicz, S., Follows, M. J., Gerber, M., Jacobson, A. R., Joos, F., Lindsay, K., Menemenlis, D., Mouchet, A., Müller, S. A., Sarmiento, J. L., and Takahashi, T.: Oceanic sources, sinks, and transport of atmospheric $\mathrm{CO}_{2}$, Global Biogeochem. Cy., 23, GB1005, doi:10.1029/2008GB003349, 2009.

Holfort, J., Johnson, K. M., Schneider, B., Siedler, G., and Wallace, D. W. R.: Meridional transport of dissolved inorganic carbon in the South Atlantic Ocean, Global Biogeochem. Cy., 12, 479499, 1998.

Houghton, R. A. and Hackler, J. L.: Carbon flux to the atmosphere from land-use changes, Trends: A compendium of data on global change, Carbon Dioxide Information Analysis Center, US Department of Energy, Oak Ridge, TN, USA, 2002.
Ito, T., Woloszyn, M., and Mazloff, M: Anthropogenic carbon dioxide transport in the Southern Ocean driven by Ekman flow, Nature, 473, 80-83, doi:10.1038/nature08687, 2010.

Keeling, C., Brix, H., and Gruber, N.: Seasonal and longterm dynamics of the upper ocean carbon cycle at station ALOHA near Hawaii, Global Biogeochem. Cy., 18, GB4006, doi:10.1029/2004GB002227, 2004.

Le Quéré, C., Rödenbeck, C., Buitenhuis, E. T., Conway, T. J., Langenfelds, R., Gomez, A., Labuschagne, C., Ramonet, M., Nakazawa, T., Metzl, N., Gillett, N., and Heimann, M.: Saturation of the Southern Ocean $\mathrm{CO}_{2}$ sink due to recent climate change, Science, 316, 1735-1738, 2007.

Le Quéré, C., Raupach, M. R., Canadell, J. G., Marland, G., Bopp, L., Ciais, P., Conway, T. J., Doney, S. C., Feely, R. A., Foster, P., Friedlingstein, P., Gurney, K., Houghton, R., A., House, J. I., Huntingford, C., Levy, P. E., Lomas, M. R., Majkut, J., Metzl, N., Ometto, J. P., Peters, G. P., Prentice, I. C., Randerson, J. T., Running, S. W., Sarmiento, J. L., Schuster, U., Sitch, S., Takahashi, T., Viovy, N., van der Werf, G. R., and Woodward, F. I.: Trends in the sources and sinks of carbon dioxide, Nat. Geosci., 2, 831-836, doi:10.10.1038/NGEO789, 2009.

Lunberg, L. and Haugan, P.: A Nordic Seas-Arctic Ocean carbon budget from volume flows and inorganic carbon data, Global Biogeochem. Cy., 10, 493-510, 1996.

Marland, G., Boden, T. A., and Andres, R. J.: Global, regional, and national $\mathrm{CO}_{2}$ emissions. Trends: $\mathrm{A}$ compendium of data on global change, Carbon Dioxide Information Analysis Center, US Department of Energy, Oak Ridge, TN, USA, 2005.

Macdonald, A. M., Baringer, M. O., Wanninkhof, R., Lee, K., and Wallace, D. W. R.: A 1998-1002 comparison of inorganic carbon and its transport across $24.5^{\circ} \mathrm{N}$ in the Atlantic, Deep Sea Res. Pt. II, 50(22-26), 3041-3064, doi:10.1016/j.dsr2.2003.07.009, 2003.

Maier-Reimer, E., Kriest, I., Segschneuder, J., and Wetzel, P.: The HAMburg Ocean Carbon Cycle Model HAMOCC5.1 Technical Description Release 1.1, Berichte zur Erdsystemforschung 14, ISSN 1614-1199, Max Planck Institute for Meteorology, Hamburg, Germany, 50 pp., 2005.

Mignone, B. K., Gnanadesikan, A., Sarmiento, J. L., and Slater, R. D.: Central role of Southern Hemisphere winds and eddies in modulating the oceanic uptake of anthropogenic carbon, Geophy. Res. Lett., 33, L01604, doi:10.1029/2005GL024464, 2006.

Mikaloff Fletcher, S. E., Gruber, N., Jacobson, A. R., Doney, S. C., Dutkiewicz, S., Gerber, M., Follows, M., Joos, F., Lindsay, K., Menemenlis, D., Mouchet, A., Müller, S. A., and Sarmiento, J. L.: Inverse estimates of anthropogenic $\mathrm{CO}_{2}$ uptake, transport, and storage by the ocean, Global Biogeochem. Cy., 20, GB2002, doi:10.1029/2005GB002530, 2006.

Mikaloff Fletcher, S. E., Gruber, N., Jacobson, A. R., Gloor, M., Doney, S. C., Dutkiewicz, S., Gerber, M., Follows, M., Joos, F., Lindsay, K., Menemenlis, D., Mouchet, A., Müller, S. A., and Sarmiento, J. L.: Inverse estimates of the oceanic sources and sinks of natural $\mathrm{CO}_{2}$ and the implied oceanic carbon transport, Global Biogeochem. Cy., 21, GB1010, doi:10.1029/2006GB002751, 2007.

Otterå, O. H., Bentsen, M., Bethke, I., and Kvamstø, N. G.: Simulated pre-industrial climate in Bergen Climate model (version 2): Model description and large-scale circulation features, Geosci. Model Dev., 2, 197-212, 2009. 
Olsen, A., Omar, A. M., Bellerby, R. G. J., Johannessen, T., Ninnemann, U., Brown, K., Olsson, A., Olafsson, J., Nondal, G., Kivimäe, C., Kringstad, S., Neill, C., and Olafsdottir, S.: Magnitude and origin of the anthropogenic $\mathrm{CO}_{2}$ increase and ${ }^{13} \mathrm{C}$ Suess effect in the Nordic seas since 1981, Global Biogeochem. Cy., 20, GB3027, doi:10.1029/2005GB002669, 2006.

Roy, T., Bopp, L., Gehlen, M., Schneider, B., Cadule, P., Froelicher, T., Segschneider, J., Tjiputra, J., Heinze, C., and Joos, F.: A model intercomparison of the regional climate-carbon cycle feedbacks from the global ocean, submitted to J. Climate, 2010.

Sabine, C. L., Key, R. M., Johnson, K. M., Millero, F. J., Poisson, A., Sarmiento, J. L., Wallace, D. W. R., and Winn, C. D.: Anthropogenic $\mathrm{CO}_{2}$ inventory of the Indian Ocean, Global Biogeochem. Cy., 13, 179-198, 1999.

Sabine, C. L., Feely, R. A., Gruber, N., Key, R. M., Lee, K., Bullister, J. L., Wanninkhof, R., Wong, C. S., Wallace, D. W. R., Tilbrook, B., Millero, F. J., Peng, T.-H., Kozyr, A., Ono, T., and Rios, A. F.: The oceanic sink for anthropogenic $\mathrm{CO}_{2}$, Science, 305, 367-371, 2004.

Sarmiento, J. L., Orr, J. C., and Siegenthaler, U.: A perturbation simulation of $\mathrm{CO}_{2}$ uptake in an ocean general circulation model, J. Geophys. Res., 97, 3621-3645, 1992.

Sarmiento, J. L., Hughes, T. M. C., Stouffer, R. J., and Manabe, S.: Simulated response of the ocean carbon cycle to anthropogenic climate warming, Nature, 393, 245-249, 1998.

Schmittner, A., Latif, M., and Schneider, B.: Model projections of the North Atlantic thermohaline circulation for the 21st century assessed by observations, Geophys. Res. Lett., 32, L23710, doi:10.1029/2005GL024368, 2005.

Schuster, U. and Watson, A. J.: A variable and decreasing sink for atmospheric $\mathrm{CO}_{2}$ in the North Atlantic, J. Geophys. Res., 112, C11006, doi:10.1029/2006JC003941, 2007.

Sitch, S., Smith, B., Prentice, I. C., Arneth, A., Bondeau, A., Cramer, W., Kaplan, J. O., Levis, S., Lucht, W., Sykes, M. T., Thonicke, K., and Venevsky, S.: Evaluation of ecosystem dynamics, plant geography and terrestrial carbon cycling in the LPJ dynamic global vegetation model, Global Change Biol., 9, 161185,2003

Smith, R. S. and Marotzke, J.: Factors influencing anthropogenic carbon dioxide uptake in the North Atlantic in models of the ocean carbon cycle, Clim. Dynam., 31, 599-613, 2008.

Steinfeldt, R., Rhein, M., Bullister, J. L., and Tanhua, T.: Inventory changes in anthropogenic carbon from 1997-2003 in the Atlantic Ocean between $20^{\circ} \mathrm{S}$ and $65^{\circ} \mathrm{N}$, Global Biogeochem. Cy., 23, GB3010, doi:10.1029/2008GB003311, 2009.
Stoll, M. H. C., van Aken, H. M., de Baar, H. J. W., and de Boer, C. J.: Meridional carbon dioxide transport in the northern North Atlantic, Mar. Chem., 55, 205-216, 1996.

Takahashi, T., Sutherland, S. C., Feely, R. A., and Wanninkhof, R.: Decadal change of the surface water $p \mathrm{CO}_{2}$ in the North Pacific: A synthesis of 35 years of observations, J. Geophys. Res., 111, C07S05, doi:10.1029/2005JC003074, 2006.

Takahashi, T., Sutherland, S. C., Wanninkhof, R., Sweeney, C., Feely, R. A., Chipman, D. W., Hales, B., Friedrich, G., Chavez, F., Sabine, C., Watson, A., Bakker, D. C. E., Schuster, U., Metzl, N., Yoshikawa-Inoue, H., Ishii, M., Midorikawa, T., Nojiri, Y., Körtzinger, A., Steinhoff, T., Hoppema, M., Olafsson, J., Arnarson, T. S., Tilbrook, B., Johannessen, T., Olsen, A., Bellerby, R., Wong, C. S., Delille, B., Bates, N. R., and de Baar, H. J. W.: Climatological mean and decadal change in surface ocean $p \mathrm{CO}_{2}$, and net sea air $\mathrm{CO}_{2}$ flux over the global oceans, Deep-Sea Res. Pt. II, 56, 554-577, 2009.

Thomas, H., Friederike Prowe, A. E., Lima, I. D., Doney, S. C., Wanninkhof, R., Greatbatch, R. J., Schuster, U., and Corbière, A.: Changes in the North Atlantic Oscillation influence $\mathrm{CO}_{2}$ uptake in the North Atlantic over the past 2 decades, Global Biogeochem. Cy., 22, GB4027, doi:10.1029/2007GB003167, 2008.

Toggweiler, J. R., Russell, J. L., and Carson, S. R.: Midlatitude westerlies, atmospheric $\mathrm{CO}_{2}$, and climate change during the ice ages, Paleoceanography, 21, PA2005, doi:10.1029/2005PA00154, 2006.

Tjiputra, J. F., Assmann, K., Bentsen, M., Bethke, I., Otterå, O. H., Sturm, C., and Heinze, C.: Bergen earth system model (BCM-C): Model description and regional climate-carbon cycle feedbacks assessment, Geosci. Model Dev., 3, 123-167, 2010.

Vázquez-Rodríguez, M., Touratier, F., Lo Monaco, C., Waugh, D. W., Padin, X. A., Bellerby, R. G. J., Goyet, C., Metzl, N., Ríos, A. F., and Pérez, F. F.: Anthropogenic carbon distributions in the Atlantic Ocean: data-based estimates from the Arctic to the Antarctic, Biogeosciences, 6, 439-451, doi:10.5194/bg-6-4392009, 2009.

Wallace, D. R.: Storage and transport of excess $\mathrm{CO}_{2}$ in the oceans: The JGOFS/WOCE Global $\mathrm{CO}_{2}$ Survey, in: Ocean Circulation and Climate, Elsevier, New York, 489-521, 2001.

Watson, A. J. and Naveira-Garabato, A. C.: The role of Southern Ocean mixing and upwelling in the glacial-interglacial atmospheric $\mathrm{CO}_{2}$ change, Tellus B, 58, 73-87, doi:10.1111/j.16000889.2005.00167.x, 2006.

Zickfeld, K., Fyfe, J. C., Saenko, O. A., Eby, M., and Weaver, A. J.: Response of the global carbon cycle to human-induced changes in Southern Hemisphere winds, Geophys. Res. Lett., 34, L12712, doi:10.1029/2006GL028797, 2007. 